\title{
Effect of Somatic Cells on Milk Quality and Human Health
}

\section{Delower Hossain $^{1,5}$, Shuvo Singha ${ }^{2,5}$, Chelsea Marie Van Thof ${ }^{3}$, Sanna Gough ${ }^{3}$ and AHM Musleh Uddin ${ }^{4,5 *}$}

${ }^{1}$ Department of Medicine and Public Health, Faculty of Animal Science and Veterinary Medicine, Sher-e-Bangla Agricultural University, Dhaka 1207, Bangladesh; ${ }^{2}$ Department of Medicine and Surgery, Faculty of Veterinary Medicine, Chattogram Veterinary and Animal Sciences University, Chattogram 4225, Bangladesh; ${ }^{3}$ Tufts University Cummings School of Veterinary Medicine, North Grafton, Massachusetts 01536, USA; ${ }^{4}$ Department of Surgery and Theriogenology, Faculty of Veterinary, Animal and Biomedical Sciences, Sylhet Agricultural University, Sylhet 3100, Bangladesh; ${ }^{5}$ Udder Health Bangladesh, Bangladesh.

Delower Hossain and Shuvo Singha contributed equally to this work as first authors.

Abstract | Somatic cells (SCs) are significant to both susceptibility and resistance of dairy cows to intramammary infections. It is used as an authentic tool for dairy farm operations in order to improve the milk quality. Broadly dimension of SCs of milk well represents the comfort and welfare of dairy cows and helps deciding efficient mastitis control strategies. Again, the safety margin evaluated though SCs ensures safe and healthy milk at consumer level devoid of bacterial presence in milk. This review highlights a brief overview of the importance and demand of estimating somatic cell count (SCC) and its effects on milk quality and human health.

Editor | Muhammad Abubakar, National Veterinary Laboratories, Park Road, Islamabad, Pakistan.

Received | November 21, 2020; Accepted | January 08, 2021; Published | February 22, 2021

*Correspondence | AHM Musleh Uddin, Department of Surgery and Theriogenology, Faculty of Veterinary, Animal and Biomedical Sciences, Sylhet Agricultural University, Sylhet 3100, Bangladesh; Email: musleh.dst@sau.ac.bd

Citation | Hossain, D., S. Singha, C.M.V.Thof, S. Gough and AHMM. Uddin. 2021. Effect of somatic cells on milk quality and human health. Veterinary Sciences: Research and Reviews, 7(1): 31-34.

DOI | http://dx.doi.org/10.17582/journal.vsrr/2021/7.1.31.34

Keywords | Somatic cells, Somatic cells, Count milk, Milk quality, Human health

\section{Introduction}

Somatic cell count ( $\mathrm{SCC}$ ) is a widely used technique $\mathcal{N}$ for the assessment of subclinical mastitis at the individual quarter, cow-level, and herd-level (Schukken et al., 2003; Petzer et al., 2017; Wollowski et al., 2019). It is also used to measure farm level improvements after the adoption of mastitis control strategies. The objective of this review is to give a brief overview of somatic cell count and its effects on milk quality and human health.

\section{Somatic cells and its function}

Somatic cells (SCs) are found in milk. They are comprised of two broad cell categories: milk secreting glandular epithelial cells and while blood cells (leucocytes) (Sharma et al., 2011; Alhussien and Dang, 2018). Leucocytes make up the majority of SC (75\%) and include neutrophils, macrophages, and lymphocytes. These cells provide a rapid response to udder infection. Epithelial cells (25\% of SC) are frequently regenerated with older cells being shed into the milk (Boutinaud and Jammes, 2002; Albenzio et al., 2019). A very small number of erythrocytes can be found in milk, ranging from 0 to $1.5 \times 10^{6}$ cells $/ \mathrm{ml}$ (Sharma et al., 2011).

Each somatic cell has its own individual function, but all contribute to protecting the udder from infection. The mammary epithelial cells activate neutrophils June 2021 | Volume 7 | Issue 1 | Page 31 
and inflammatory mediators after the release of bacterial toxins and enzymes within the teat canal results edema, vasodilatation and increased vascular permeability (Nonnecke and Harp, 1986; Goldstein et al., 1992). Neutrophils defend against infection by engulfing and destroying bacteria that gain entry to the teat canal. Monocytes turn into macrophages when activated, and play a similar role to neutrophils by phagocytizing bacterial cells. They also release proteases and reactive oxygen molecules to damage nearby bacteria (Park et al., 1992). Lymphocytes provide a more refined immune response than neutrophils or monocytes. Through membrane receptors lymphocytes identify and remember the antigenic structures of bacterial proteins so that the body can more rapidly mount an immune response in the future. SC composition varies depending on the type of mammary secretion (colostrums, milk, or dry gland secretion). For example, leukocytes are present in a much higher concentration in colostrums when compared to milk and dry gland secretion (Sharma et al., 2011).

\section{Effect SCs on milk quality and human health}

A higher SCC in milk is attributable to inflammation in the udder, typically due to a bacterial infection (Wollowski et al., 2019; Stocco et al., 2020). A high SCC alters milk quality and composition, making it unfit for safe human consumption (Sharma et al., 2011; Dos Reis et al., 2013; Kull et al., 2019; Stocco et al., 2020). Some reviews showed that a BMSCC $>500,000$ cells $/ \mathrm{mL}$ was associated with higher proteolytic activity, whey protein (serum albumin and immunoglobulin) and lower the concentrations of fat and protein which reduces the cheese quality (Skeie, 2010; Moradi et al., 2020). Accurate SC measurements are not available in many developing countries, so SCC data and guidelines are often insufficient. In general, a bulk milk somatic cell count (BMSCC) greater than 300,000 cells $/ \mathrm{mL}$ of milk is considered a clear indication of herd infection and warrants further identification of individual lactating animals (Constable et al., 2017). However, the reported threshold level of SC varies widely between countries. The European Union, New Zealand, Switzerland, Australia and Canada have all ruled that a BMSCC exceeding 400,000 cells $/ \mathrm{mL}$ is not allowed for consumption. In contrast, the United States pasteurized milk ordinance (2015) considered up to 750,000 cells $/ \mathrm{mL}$ acceptable (Alhussien and Dang, 2018; Kelly et al., 2018).
A high milk SCC is a human health concern, a fact which has recently gained attention in national mastitis council (NMC) discussions. Many causative pathogens of human diseases (i.e. E. coli, Staphylococcus aureus, Streptococcus agalactiae) also cause of intramammary infections in cattle and high milk SCC, making the milk hazardous for human consumption (Petzer et al., 2017; Ewida and A1-Hosary, 2020; Yun et al., 2020). While pasteurization is capable of killing the majority of pathogenic bacteria found in milk, some bacteria, such as Mycobacterium avium, Mycobacterium paratuberculosis, Listeria monocytogenes, Bacillus spp. and Clostridium spp. can still survive (Grant et al., 1996; Binderova and Rysanek, 1999; Gunasekera et al., 2002; NMC, 2016). Pasteurization also cannot neutralize the toxins already released by the pathogenic bacteria in milk (NMC, 2016). To relate this information mentioned, level of SCC is a good indicator of farm hygiene and unpasteurized milk and milk products can transmit even wider range of pathogenic bacteria for human health risk.

Emphasis on milk SCC measurements can greatly improve milk quality and farm level hygiene (Ruegg and Pantoja, 2013; Ndahetuye et al., 2020). An increased SCC reflects an intramammary infection, so monitoring SCC provides farms with an opportunity to check for disease progression/improvement. A monthly assessment of SCC in a herd can also be indicative of the overall farm management and validate changes in management practices. Overall, $\mathrm{SCC}$ is a very efficient and convenient technique to incorporate in a mastitis control program to ensure that milk meets the safety standard for human consumption.

\section{Novelty Statement}

Somatic cell count is a crucial indicator for estimating mammary health and milk quality. Our review paper independently focuses on the new concept based relationship of human health with SCC.

\section{Author's Contribution}

All authors contributed to write and read the manuscript and agree to be responsible for any aspect of the manuscript.

\section{Conflict of interest}

The authors have declared no conflict of interest. 


\section{References}

Albenzio, M., L. Figliola, M. Caroprese, R. Marino, A. Sevi and A. Santillo. 2019. Somatic cell count in sheep milk. Small Ruminant Res., 176: 24-30. https://doi.org/10.1016/j. smallrumres.2019.05.013

Alhussien,M.N.and A.K.Dang.2018.Milk somatic cells, factors influencing their release, future prospects, and practical utility in dairy animals: An overview. Vet. World, 11: 562. https://doi. org/10.14202/vetworld.2018.562-577

Binderova, E. and D. Rysanek. 1999. Microbial contaminants of milk processes by hightemperature short-time pasteurization. Veterinarni Medicina-UZPI (Czech Republic).

Boutinaud, M. and H. Jammes. 2002. Potential uses of milk epithelial cells: A review. Reprod. Nutr. Dev., 42: 133-147. https://doi.org/10.1051/ rnd:2002013

Constable, P.D., K.W. Hinchcliff, S.H. Done and W. Grünberg. 2017. 20 Diseases of the mammary gland, In: Veterinary Medicine (Eleventh Edition). W.B. Saunders.

Ewida, R.M. and A.A.T. Al-Hosary. 2020. Prevalence of enterotoxins and other virulence genes of Staphylococcus aureus caused subclinical mastitis in dairy cows. Vet. World, 13: 1193. https://doi.org/10.14202/ vetworld.2020.1193-1198

Goldstein, I.M., R. Snyderman and J.I. Gallin. 1992. Inflammation: Basic principles and clinical correlates. Raven Press.

Grant, I.R., H.J. Ball, S.D. Neill and M.T. Rowe. 1996. Inactivation of Mycobacterium paratuberculosis in cows' milk at pasteurization temperatures. Appl. Environ. Microbiol. 62: 631-636. https://doi.org/10.1128/ AEM.62.2.631-636.1996

Gunasekera, T.S., A. Sørensen, P.V. Attfield, S.J. Sørensen and D.A. Veal. 2002. Inducible gene expression by nonculturable bacteria in milk after pasteurization. Appl. Environ. Microbiol., 68: 1988-1993. https://doi.org/10.1128/ AEM.68.4.1988-1993.2002

Kelly, A.L., G. Leitner and U. Merin. 2018. Milk quality and udder health: Test methods and standards. https://doi.org/10.1016/B978-008-100596-5.00951-3

Kull, E., A. Sahin, S. Atasever, E. Ugurlutepe and M. Soydaner. 2019. The effects of somatic cell count on milk yield and milk composition in Holstein cows. https://doi.org/10.24099/vet. arhiv.0168

Moradi, M., A.K. Omer, R. Razavi, S. Valipour, and J.T. Guimarães. 2020. The relationship between milk somatic cell count and cheese production, quality and safety: A review. Int. Dairy J., pp. 104884. https://doi.org/10.1016/j. idairyj.2020.104884

Ndahetuye, J.B., K. Artursson, R. Båge, A. Ingabire, C. Karege, J. Djangwani, A.-K. Nyman, M.P. Ongol, M. Tukei and Y. Persson. 2020. MILK Symposium review: Microbiological quality and safety of milk from farm to milk collection centers in Rwanda. J. Dairy Sci., 103: 97309739. https://doi.org/10.3168/jds.2020-18302

NMC, 2016. Human health risks associated with high somatic cell count milk https://www. nmconline.org/wp-content/uploads/2016/.

Nonnecke, B.J. and J.A. Harp. 1986. Effect of chronic staphylococcal mastitis on mitogenic responses of bovine lymphocytes1.J. Dairy Sci., 68: 3323-3328. https://doi.org/10.3168/jds. S0022-0302(85)81242-X

Park, Y.H., L.K. Fox, M.J. Hamilton and W.C. Davis. 1992. Bovine mononuclear leukocyte subpopulations in peripheral blood and mammary gland secretions during lactation. J. Dairy Sci., 75: 998-1006. https://doi. org/10.3168/jds.S0022-0302(92)77842-4

Petzer, I.-M.,J.Karzis, E.F.Donkin, E.C.Webb and E. Etter. 2017. Somatic cell count thresholds in composite and quarter milk samples as indicator of bovine intramammary infection status. Onderstepoort J. Vet. Res., 84: 1-10. https://doi.org/10.4102/ojvr.v84i1.1269

Dos Reis, C.B.M., J.R. Barreiro, L. Mestieri, M.A. de Felício Porcionato and M.V. dos Santos. 2013. Effect of somatic cell count and mastitis pathogens on milk composition in Gyr cows. BMC Vet. Res., 9: 67. https://doi. org/10.1186/1746-6148-9-67

Ruegg,P.L.and J.C.F.Pantoja.2013.Understanding and using somatic cell counts to improve milk quality. Irish J. Agric. Food Res., pp. 101-117.

Schukken, Y.H., D.J. Wilson, F. Welcome, L. Garrison-Tikofsky and R.N. Gonzalez. 2003. Monitoring udder health and milk quality using somatic cell counts. Vet. Res., 34: 579596. https://doi.org/10.1051/vetres:2003028

Sharma, N., N.K. Singh, and M.S. Bhadwal. 2011. 
Relationship of somatic cell count and mastitis: An overview. Asian Aust.J. Anim. Sci., 24: 429_ 438. https://doi.org/10.5713/ajas.2011.10233

Skeie, S., 2010. Milk quality requirements for cheesemaking. Elsevier. https://doi. org/10.1533/9781845699437.3.432

Stocco, G., A. Summer, C. Cipolat-Gotet, L. Zanini, D. Vairani, C. Dadousis and A. Zecconi. 2020. Differential somatic cell count as a novel indicator of milk quality in dairy cows. Animals, 10: 753. https://doi.org/10.3390/ani10050753
Wollowski, L., S. Bertulat, A. Kossatz and W. Heuwieser. 2019. Diagnosis and classification of clinical and subclinical mastitis utilizing a dynamometer and a handheld infrared thermometer. J. Dairy Sci., 102: 6532-6539. https://doi.org/10.3168/jds.2018-15509

Yun, M.-J., S. Yoon, and Y.J. Lee. 2020. Monitoring and characteristics of major mastitis pathogens from bulk tank milk in Korea. Animals, 10: 1562. https://doi.org/10.3390/ani10091562 